\title{
Vraag naar publieke zorg zal extra stijgen door achterblijven aanbod informele hulp
}

\author{
Isolde Woittiez (D) - Michiel Ras · Evelien Eggink • Debbie Verbeek-Oudijk
}

Geaccepteerd op: 7 april 2021 / Published online: 12 mei 2021

(C) The Author(s) 2021

\begin{abstract}
Samenvatting Door de dubbele vergrijzing zal in $\mathrm{Ne}$ derland het aantal mensen met zorg en ondersteuning de komende twee decennia toenemen. We berekenen om hoeveel mensen het gaat en welk type zorg en ondersteuning het meest zal stijgen. Naast publiek gefinancierde hulp uit de Wmo (hulp bij het huishouden, begeleiding), de Zvw (wijkverpleging) en de Wlz (verpleeghuiszorg) gaat het om informele hulp en zelf betaalde hulp. We onderzoeken ook de effecten van de verwachtingen over een krimpend potentieel aanbod van informele hulp. Op basis van een statistisch model en trends in de verklarende factoren voor zorggebruik construeren we twee ramingsvarianten: één met en één zonder rekening te houden met de verwachte afname in het aanbod van informele hulp. Het totale gebruik van zorg en ondersteuning stijgt volgens de raming zonder aanbodrestricties tot 2040 met bijna 20\% (bijna 350.000 volwassenen). De sterkste groeiers zijn zelf betaalde hulp, verpleeghuiszorg en wijkverpleging. Het aantal gebruikers van publiek gefinancierde zorg en ondersteuning zal naar schatting met 200.000 volwassenen toenemen. Wanneer het aanbod van informele hulp zoals verwacht achterblijft kan die groei zelfs 270.000 volwassenen betreffen. Inzetten op mantelzorgondersteuning, domotica en het uitbreiden van het sociale netwerk van ouderen kan deze stijging wellicht verminderen.
\end{abstract}

Trefwoorden toekomstig zorggebruik · ouderen · langdurige zorg · informele hulp

\footnotetext{
Digitaal aanvullende content De online versie van dit artikel (https://doi.org/10.1007/s12508-021-00295-x) bevat aanvullend materiaal, toegankelijk voor daartoe geautoriseerde gebruikers.

I. Woittiez (ه) · M. Ras · E. Eggink · D. Verbeek-Oudijk Sociaal en Cultureel Planbureau, Den Haag, Nederland i.woittiez@scp.nl
}

\begin{abstract}
The number of Dutch adults receiving care and support will rise during the next decennia because of double-ageing. We estimate the number of adults involved and the growth rates of the different types of care and support. Apart from publicly financed Wmo-care (household help and assistance), Zvw-care (nursing) and Wlz-care (nursing homes), we analyze informal care and self-paid care as well. We also analyze the impact of an expected decline in the potential supply of informal care. Based on a statistical model and trends in the explanatory variables for care use we construct two future care variants: one with and one without taking into account the expected decrease in informal care supply. Without informal care supply restrictions, the total use of care and support will rise with $20 \%$ (almost 350,000 adults) until 2040 according to our calculations. Self-paid care, nursing homes and nursing care will grow faster than other care types. The number of adults receiving publicly financed care and support will increase with 200,000. If informal care supply stays behind as expected, the increase is 270,000 adults. Additional efforts to increase informal care by giving support, home automation and expansion of social networks of elderly may reduce this increase.
\end{abstract}

Keywords future care use · elderly · long-term care · informal care

\section{Inleiding}

De uitgaven aan langdurige zorg en ondersteuning in Nederland zullen de komende twee decennia naar verwachting verder toenemen, net als in andere Europese landen [1-4]. Dat komt door de dubbele vergrijzing van de Nederlandse bevolking (het aandeel 80-plussers stijgt sneller dan het aandeel 65- tot 80jarigen [5]) en doordat ouderen doorgaans met meer 
gezondheidsproblemen kampen dan de jongere generaties. Het beroep op zorgvoorzieningen neemt dan ook toe naarmate men ouder wordt $[2,6]$. Een deel van de hulpbehoevenden, vaak ouderen met ernstige lichamelijke beperkingen of dementie, ontvangt publiek gefinancierde zorg. Voor zowel de toekomstige financiële middelen als het personeel is het essentieel inzicht te hebben in toekomstige veranderingen in het gebruik van langdurige zorg en ondersteuning.

Beleidsmatig zijn er stappen gezet om de verwachte kostenstijging te beperken. Zo wordt ernaar gestreefd ouderen zo lang mogelijk thuis te laten wonen [7]. Daartoe is een deel van de zorg en ondersteuning in de thuissituatie onder verantwoordelijkheid van de gemeenten (Wmo 2015) en de zorgverzekeraars gebracht $(\mathrm{Zvw})$, en is de instellingszorg beperkt tot mensen die 24 uur per dag hulp nodig hebben (Wlz). Daarnaast wordt er meer een beroep gedaan op de burger zelf en zijn of haar naasten [7]. Maar in de komende jaren zal het aantal potentiële mantelzorgers waarschijnlijk minder snel toenemen dan de vraag ernaar [8].

In dit artikel maken we een raming van het gebruik van zorg en ondersteuning in 2040. Dat doen we op basis van een statistisch model, langs de lijnen van een onderzoek van het Sociaal en Cultureel Planbureau [9]. Het model relateert de ontvangen hulp aan kenmerken van de ontvangers, bijvoorbeeld hun gezondheid en hun leeftijd. We ramen naast het gebruik van publieke zorg, ook zelf betaalde en informele hulp vanuit het eigen netwerk. Op basis van het statistische model en trends in de kenmerken van de bevolking construeren we twee ramingsvarianten (zie ook [10]). Beide varianten gaan uit van ongewijzigd beleid en ongewijzigde preferenties. Zo nemen we onder andere aan dat de spanning tussen de vraag naar en het aanbod van publieke zorg en ondersteuning constant blijft in de toekomst. Dit impliceert bijvoorbeeld dat de ontwikkeling van het aanbod van zorgpersoneel gelijke tred houdt met de ontwikkeling van de vraag ervan, en dat gedragsrelaties niet veranderen. We maken eerst een raming van het zorggebruik die geheel gebaseerd is op de ontwikkelingen in de kenmerken. Hierbij gaan we ervanuit dat het aanbod van alle hulpvormen voldoende is om aan de groeiende vraag tegemoet te komen. De tweede raming gaat ervan uit dat dit niet het geval zal zijn en baseert zich op de verwachte afname in het aanbod van informele hulp [8]. (Met eenzelfde analyse zou ook de invloed van een toe- of afname van zelf betaalde hulp kunnen worden doorgerekend. Dit valt echter buiten de scope van dit artikel).

De meerwaarde van onze ramingen boven die van het RIVM en het CPB is dat ze informele, zelf betaalde én publiek gefinancierde hulp in hun onderlinge samenhang bekijken en de mogelijkheid bieden beleidsvarianten door te rekenen [2, 3].

\section{Data en methode}

\section{Data}

Voor de analyses gebruiken we gegevens over zelfstandig wonenden en verpleeghuisbewoners in $\mathrm{Ne}$ derland. We maken gebruik van de enquête Onderzoek Zorggebruik (OZG) uit de periode 2014-2016 onder ongeveer 7.800 18-plussers die zelfstandig wonen [11]. Deze cijfers weerspiegelen het gemiddelde over een periode van drie jaar (2014-2016). Uit eerdere onderzoeken is gebleken dat zowel het zorggebruik als de kenmerken van de respondenten in deze jaren niet veranderd zijn [11]. Daarom is het voor onze analyse mogelijk deze jaargangen samen te nemen. Deze informatie is aangevuld met het Onderzoek Ouderen in Instellingen (OII) uit 2015/2016. Deze enquête is gehouden onder ongeveer 1.600 mensen van 55 jaar en ouder, die permanent in een verpleeghuis verblijven [12]. Aangezien slechts ongeveer $3 \%$ van de verpleeghuisbewoners jonger is dan 55 jaar zal deze leeftijdsgrens de resultaten vrijwel niet verstoren [13]. De gecombineerde enquêtegegevens betreffen dus ongeveer 9.400 volwassenen die rond 2015 thuis of in een verpleeghuis woonden. Alle respondenten zijn dezelfde vragen gesteld over individuele kenmerken en het gebruik van zorg en ondersteuning.

Gedurende de enquêteperiode werden de Wlz, de Wmo 2015 en de Zvw ingevoerd. Sinds 2015 is de toegang tot verpleeghuiszorg aangescherpt en is de zorgbehoefte van (nieuwe) verpleeghuisbewoners gemiddeld genomen hoger. De lichtere vormen van verpleeghuiszorg (zorgzwaartepakket 1 tot en met 3) zijn niet langer beschikbaar (ongeveer $10 \%$ van de verpleeghuisbewoners [9, 14]). Mensen blijven langer thuis wonen wanneer zij gezondheidsbeperkingen krijgen en vaker een beroep doen op hun eigen netwerk en financiële middelen. Verder is het budget voor huishoudelijke hulp bij de invoering van de Wmo 2015 flink gekort.

We gebruiken de enquêtegegevens om de relaties tussen kenmerken van mensen en de kans op zorggebruik vast te stellen. We denken dat deze relaties ook in de toekomst op hoofdlijnen geldig zijn voor een situatie waarin beleid ongewijzigd zou blijven. Er zijn sinds de invoering van de Wmo geen grote verschuivingen zichtbaar in het gebruik van zware naar lichte hulp zoals bedoeld met deze wet [7].

\section{Zorgpakketten}

We betrekken in dit onderzoek naast publiek gefinancierde ook informele en zelf betaalde zorg en ondersteuning. Curatieve zorg van bijvoorbeeld de huisarts of het ziekenhuis en paramedische en psychosociale zorg worden niet geraamd. Iemand kan verschillende vormen van zorg en ondersteuning tegelijk ontvangen. Om dubbeltellingen van ontvangers van hulp te voorkomen, delen we gebruikers in bij de zwaar- 
ste zorgvorm die zij ontvangen en maken zo 'zorgpakketten'. Een zorgpakket wordt dus bepaald door de zwaarste zorgvorm die wordt ontvangen, maar kan daarnaast ook lichtere zorgvormen bevatten. Op deze manier komen we tot de volgende zorgpakketten (voor meer uitleg over de inhoud van de zorgpakketten verwijzen we naar paragraaf 2.2.1 van [9]):

- geen hulp: geen zorg en ondersteuning;

- informele hulp: alleen zorg en ondersteuning van familie en het sociale netwerk (hulp gefinancierd via een persoonsgebonden budget (pgb) rekenen we tot de publiek gefinancierde hulp, ook wanneer het pgb wordt gebruikt om een familielid te compenseren voor de geleverde hulp);

- zelf betaalde hulp: mogelijk samen met de hiervoor genoemde zorgvormen;

- huishoudelijke hulp: publiek gefinancierde huishoudelijke hulp (Wmo 2015), mogelijk samen met de hiervoor genoemde zorgvormen;

- begeleiding: publiek gefinancierde begeleiding (Wmo 2015), mogelijk samen met de hiervoor genoemde zorgvormen;

- wijkverpleging: wijkverpleging vanuit de Zvw, mogelijk samen met de hiervoor genoemde zorgvormen;

- verpleeghuiszorg vanuit de Wlz. (Vormen als logeeropvang, crisiszorg, revalidatie en eerstelijnsverblijf vallen dus buiten het bestek van het onderzoek. Verder bevatten onze databestanden geen informatie over het volledige pakket thuis (vpt) en modulair pakket thuis (mpt). Dit is in ons model onder een van de genoemde zorgpakketten opgenomen. Bij verpleeghuiszorg gaat het om een all-in-pakket waar alle zorgvormen onder vallen.)

Het merendeel van de Nederlandse volwassenen heeft geen aandoeningen of beperkingen. Ruim $82 \%$ van de Nederlandse 18-plussers ontvangt in 2018 dan ook geen hulp (linkerdeel van fig. 1). (Deze cijfers wijken af van de cijfers in [9] omdat daar alleen gekeken is naar mensen met een gezondheidsbeperking. Daarnaast hebben we de enquêtecijfers hier geijkt aan de registraties van zorg en ondersteuning.) Van de $18 \%$ zorg- gebruikers is de groep die alleen informele hulp ontvangt veruit de grootste (41\% van de zorggebruikers), op afstand gevolgd door de mensen die de zorgpakketten wijkverpleging (15\%), zelf betaalde hulp (13\%), begeleiding (12\%) of huishoudelijke hulp (12\%) ontvangen (rechterdeel van fig. 1). Zes procent van de zorgontvangers woont in een verpleeghuis.

\section{Methode}

Dit onderzoek past in een onderzoekstraditie naar het gebruik van zorg en ondersteuning van het Sociaal en Cultureel Planbureau [9, 16-19]. Met een statistisch model is de relatie tussen het gebruik van zorg en ondersteuning en verschillende individuele kenmerken berekend. In de ramingen wordt die relatie in toekomstige jaren als constant verondersteld. De basisgedachte van de raming is dus dat de ontwikkeling in het zorggebruik geheel bepaald wordt door de ontwikkeling in kenmerken van de bevolking. Ter illustratie: ouderen hebben een grotere kans op zorggebruik, dus een toename van het aantal ouderen leidt in de raming tot meer gebruik van zorg.

Als basis van de raming nemen we de werkelijke aantallen ontvangers van zorg en ondersteuning in 2018 [15]. We ijken het niveau van onze ramingen in 2018 aan de landelijke registraties over het aantal gebruikers van de pakketten huishoudelijke hulp, begeleiding, wijkverpleging en verpleeghuiszorg. Er zijn geen landelijke registraties van het gebruik van informele en zelf betaalde hulp. We passen hier dezelfde gemiddelde procentuele correctie toe als bij zorg thuis (huishoudelijke hulp, begeleiding en wijkverpleging samen). Het ijken heeft gevolgen voor het niveau van het geraamde gebruik, maar niet voor de geraamde procentuele groei. IJken aan de aantallen in 2015 zou de uitkomsten niet veel veranderen. Zie het supplement voor meer methodische informatie.

We construeren twee ramingsvarianten. In de ene variant is de raming van informele hulp en de andere zorgpakketten louter gebaseerd op de trends in de individuele kenmerken van de bevolking. In de andere wordt de raming van het toekomstig gebruik van in-
Figuur 1 Verdeling van zorgpakketten over de bevolking van 18 jaar en ouder (in procenten) (2018). Bron: CBS maatwerktabel [15], SCP-bewerking

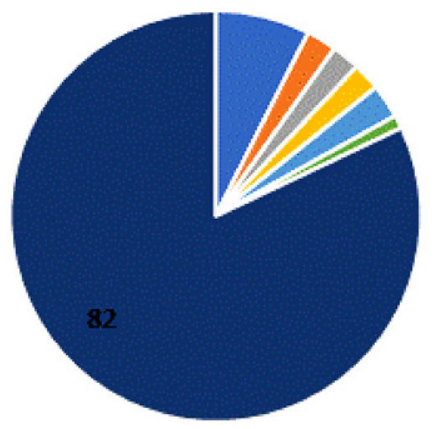

- geen hulp

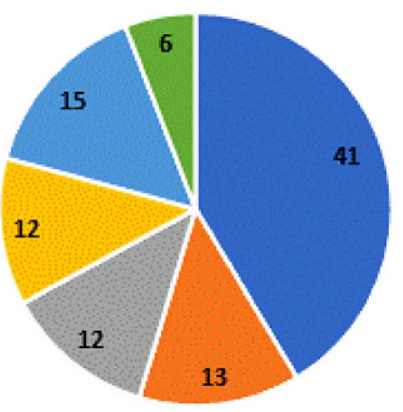

- informelehulp $\quad$ zef betaaldehulp w huishoudelijke hulp

a begeleiding = wikverpleging =verpleeghuişorg 
formele hulp met $40 \%$ naar beneden bijgesteld. We doen dit door de kans op het pakket met alleen informele hulp naar beneden bij te stellen. Wie binnen een 'hoger' pakket ook informele hulp ontvangt, zal bij het wegvallen van informele hulp niet van pakket veranderen. De bijstelling is gebaseerd op de verwachting dat het aanbod van informele hulp in de komende jaren slechts aan $60 \%$ van de gestegen vraag tegemoet kan komen (volgens [8] zal de ratio tussen het aantal potentiële mantelzorgers en het aantal zorgvragers afnemen van vijf tot drie). We weten dat voor een kwart van de ontvangers van alleen informele hulp een overstap naar duurdere publiek gefinancierde zorg te verwachten valt als er geen informele hulp beschikbaar zou zijn [9]. Deze informatie gebruiken we in de raming.

\section{Statistisch model}

Net als in andere onderzoeken volgen we voor het verklaren van het zorggebruik in grote lijnen het gangbare theoretische model van Andersen en Newman [6, 9, $16,20,21]$. Volgens hen spelen drie groepen factoren een rol bij het ontvangen van zorg: individuele kenmerken van de bevolking, omgevingsfactoren en kenmerken van het zorgsysteem. Net als de meeste andere Nederlandse onderzoeken, focussen wij voornamelijk op de individuele kenmerken.

Om de relatie tussen het gebruik enerzijds en de individuele kenmerken anderzijds te bepalen, hanteren we een multinomiaal logistisch regressiemodel (zie tabel S. 1 in het supplement voor de resultaten). Bij individuele kenmerken gaat het om iemands hulpbehoefte, persoonskenmerken en hulpbronnen. Als indicatoren voor iemands hulpbehoefte gebruiken we het hebben van lichamelijke beperkingen, een verlaagd psychisch welbevinden, ernstige geheugenklachten, minimaal twee chronische aandoeningen, het gebruik van loophulpmiddelen, en bezoek aan een fysiotherapeut of ziekenhuis. Kenmerken die een slechtere gezondheid weerspiegelen, vooral het hebben van een lichamelijke beperking, zijn (bij gelijke scores op de andere kenmerken) positief gerelateerd aan het ontvangen van zorg (tabel S. 1, supplement). Het hebben van (ernstige) geheugenklachten is positief gerelateerd aan het gebruik van verpleeghuiszorg. De kans op het gebruik van de meeste zorgpakketten hangt ook samen met persoonskenmerken (leeftijd en geslacht). De kans op zorg is groter naarmate men ouder is, en vrouwen gebruiken vaker (informele of zelf betaalde) hulp dan mannen (bij gelijke overige kenmerken). Indicatoren voor iemands hulpbronnen zijn de aanwezigheid van een partner, iemands inkomen en opleidingsniveau. De kans op informele hulp is voor verweduwden kleiner dan voor anderen, terwijl het nooit gehuwd geweest zijn in sterke mate bijdraagt aan het gebruik van professionele hulp. Verder is een hoger inkomen of hoger opleidingsniveau negatief gerelateerd aan de kans op verpleeghuiszorg en positief gerelateerd aan de kans op het ontvangen van zelf betaalde hulp. Alle geschatte effecten zijn in overeenstemming met wat in de literatuur beschreven is [9].

\section{Trends in individuele kenmerken}

De steekproef waarop het statistische model is geconstrueerd geeft via weging een representatief beeld van de Nederlandse bevolkingssamenstelling. De gewichten zijn geconstrueerd op basis van cijfers van het Centraal Bureau voor de Statistiek (CBS) en het Rijksinstituut voor Volksgezondheid en Milieu (RIVM) voor zo veel mogelijk kenmerken in het model. Die betreffen leeftijd, geslacht, huishoudsamenstelling, opleidingsniveau, lichamelijke beperkingen, ernstige geheugenklachten, en het hebben van twee of meer chronische aandoeningen (zie noot $\mathrm{c}$ in tabel S. 1 in het supplement) (niet opgenomen zijn psychisch welbevinden, loophulpmiddelen, bezoek aan fysiotherapeut en ziekenhuis, inkomen en stedelijkheid; hiervoor waren geen goede ramingen beschikbaar of werd geen grote bijdrage verwacht).

We construeren ook gewichten voor 2040, zodat de steekproef ook de samenstelling van de bevolking in dat jaar kan beschrijven ('bevolkingsmodel'). De gewichten zijn gebaseerd op een combinatie van prognoses. Voor de demografie is uitgegaan van de bevolkingsprognose van het CBS [22]. Dit is de meest recente bevolkingsprognose waarin de huishoudpositie is geraamd. Dit is aangevuld met [13] voor het jaar 2018. Hierin zijn de omvang en verdeling van de bevolking naar leeftijd, geslacht en huishoudtype geraamd. Er zijn nog geen indicaties dat de coronaepidemie de bevolkingsraming voor 2040 zal veranderen [23]. Voor het opleidingsniveau is de verdeling in 2018 gebruikt [24, 25], en hebben we 2040 geraamd via het ouder worden van cohorten in de loop der tijd, met een correctie voor opleidingsspecifieke sterfte [26]. Lager opgeleiden sterven gemiddeld jonger. Mogelijke effecten van immigratie en emigratie zijn niet meegenomen. Voor lichamelijke beperkingen, dementie en het hebben van twee of meer aandoeningen gebruiken we ramingen van het RIVM (we hebben achterliggend cijfermateriaal ontvangen van het RIVM; soms hebben we aannamen gedaan om de RIVM-raming beter aan te laten sluiten op onze data en steeds is de groei die het RIVM voorziet overgenomen) [2].

De kenmerken ontwikkelen zich als volgt. Het aantal 18-plussers stijgt tussen 2018 en 2040 naar verwachting met $8 \%$ (tab. 1) van 13,6 miljoen naar 14,7 miljoen. Bij de (demografische) persoonskenmerken valt de verdubbeling van het aantal 80 -plussers op van 0,8 miljoen naar 1,6 miljoen mensen, naast de eveneens flinke stijging (48\%) van het aantal 65- tot 79-jarigen in 2040. Minder snel stijgen de aantallen alleenstaanden (nooit gehuwd geweest) en verweduwden (respectievelijk $10 \%$ en 13\%). Alle 
indicatoren van de hulpbehoefte laten in 2040 een hoger niveau zien. Het meest stijgt het aantal mensen met ernstige geheugenklachten (73\%). Ook het aantal mensen met twee of meer chronische aandoeningen stijgt als gevolg van de vergrijzing harder dan de bevolking. Opvallend is dat het aantal mensen met een matige of ernstige lichamelijke beperking ongeveer gelijk opgaat met de bevolking. Per leeftijdsgroep neemt dat aandeel af, maar dit wordt gecompenseerd door de vergrijzing [2]. Het aantal hoogopgeleiden neemt sterk toe $(41 \%)$ en het aantal laagopgeleiden daalt sterk (32\%).

\section{Resultaten}

Door de bevolkingsgroei, maar meer nog door de dubbele vergrijzing zal het aantal mensen dat zorg ontvangt bij een 'meelopend' aanbod van mantelzorg tussen 2018 en 2040 naar verwachting met 330.000 mensen stijgen. Dat betekent een groei van $19 \%$ in het totale zorggebruik (fig. 2). Dat is veel minder dan de groei in de omvang van de 65-plus-bevolking (bijna 50\%) en in de 80-plus-bevolking (meer dan $100 \%)$, maar meer dan de groei van de 18-plus-bevolking (8\%, tab. 1). De grootste stijging is zichtbaar bij de zelf betaalde hulp (59\%) en de zwaarste zorgvormen: verpleeghuiszorg (54\%) en wijkverpleging (30\%) (fig. 2). Dat steeds meer mensen zelf hulp zullen inkopen komt vooral doordat er meer mensen zijn met hogere opleidingsniveaus. De toename in verpleeghuiszorg heeft vooral te maken met de verdergaande vergrijzing, die leidt tot meer mensen met dementie. Hoewel het om een procentueel grote toename gaat, blijft het een relatief kleine, maar dure groep (de stijging betreft 66.000 mensen).

Bij een 'meelopend' aanbod van informele hulp neemt het gebruik van informele hulp af met $1 \%$. In de ramingsvariant met een $40 \%$ lager aanbod is er in 2040 sprake van een flinke afname ten opzichte
Tabel 1 Ontwikkeling in aantal mensen van 18 jaar en ouder naar individuele kenmerken (2018-2040)

\begin{tabular}{|l|c|}
\hline Bevolking & Groei (\%) \\
\hline Hulpbehoefte & 8 \\
\hline - geen of lichte lichamelijke beperking & \\
\hline - matige of ernstige lichamelijke beperking & 7 \\
\hline - geen verlaagd psychisch welbevinden & 8 \\
\hline - verlaagd psychisch welbevinden & 9 \\
\hline - geen ernstige geheugenklachten & 1 \\
\hline - (ernstige) geheugenklachten & 6 \\
\hline - geen of één aandoening & 73 \\
\hline - twee of meer aandoeningen & 4 \\
\hline Persoonskenmerken & 19 \\
\hline - 18-64 jaar & \\
\hline - 65-79 jaar & -5 \\
\hline - $\geq 80$ jaar & 48 \\
\hline - man & 106 \\
\hline - vrouw & 7 \\
\hline Hulpbronnen & 8 \\
\hline - paar & \\
\hline - alleenstaand (nooit gehuwd geweest) & 5 \\
\hline - verweduwd & 10 \\
\hline - huishoudinkomen $\leq 1.199$ euro & 13 \\
\hline - huishoudinkomen 1.200-1.799 euro & 3 \\
\hline - huishoudinkomen $\geq 1.800$ euro & 6 \\
\hline - laag opgeleid & 10 \\
\hline - middelbaar opgeleid & -32 \\
\hline - hoog opgeleid & 8 \\
\hline Bron: SCP/CBS (0ZG'14-'16, Oll'15/'16); [2, 13, 22, 24-26]; SCP-bewerking \\
\hline
\end{tabular}

Figuur 2 Geraamde verandering in zorggebruikers in 2040, absolute aantallen $(\times 1.000)$ in 2018 en gemiddelde groei ten opzichte van 2018 in procenten. De bolletjes geven het aantal gebruikers in 2018 weer (×1.000); de staafjes geven de groei in 2040 ten opzichte van dit gebruik voor de twee ramingsvarianten. Bron: SCP/CBS (OZG'14'16, OII'15/'16); [2, 13, 22, 24-26]; SCP-bewerking

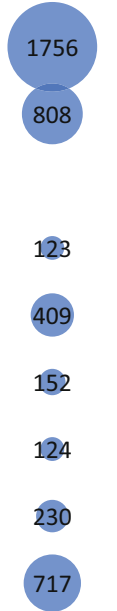

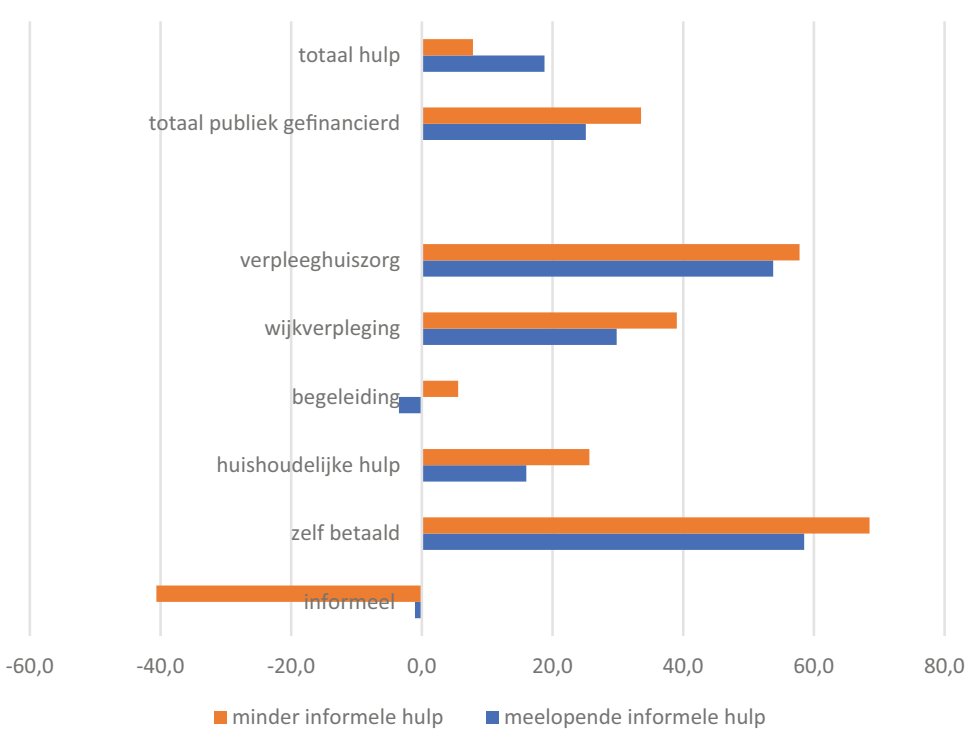


van $2018(-41 \%)$. Een groot deel van de groep die geen informele hulp meer kan ontvangen zal volgens onderzoek van het SCP relatief zelfredzaam zijn en helemaal geen hulp ontvangen [9]. Bijna een kwart van de mensen met informele hulp heeft echter dusdanige gezondheidsbeperkingen dat publiek gefinancierde zorg en ondersteuning naar schatting het meest waarschijnlijke alternatief zou zijn [9]. Naar verwachting zouden in 2040 bijna 70.000 extra mensen een beroep doen op publiek gefinancierde hulp. Het aantal gebruikers van publiek gefinancierde zorg en ondersteuning groeit 9 procentpunten meer in de raming met een achterblijvend aanbod van informele hulp (34\% in plaats van $25 \%$, fig. 2). Er zullen naar verwachting meer gebruikers zijn van alle vormen van publiek gefinancierde zorg; voor een kleine groep komt zelfs opname in een verpleeghuis in zicht [9]. Hun problematiek is zo groot dat bij het wegvallen van de informele hulp meteen zware zorg in beeld komt. Toch zullen minder mensen zorg ontvangen omdat het wegvallen van informele hulp niet volledig gecompenseerd wordt door de andere vormen van hulp.

\section{Beschouwing en conclusie}

Het gebruik van publiek gefinancierde zorg en ondersteuning zal bij ongewijzigd beleid en preferenties tot 2040 naar verwachting tussen $25 \%$ en $34 \%$ stijgen, afhankelijk van de ontwikkeling van het aanbod van mantelzorg. Deze cijfers vormen in zekere zin goed nieuws: het gebruik stijgt veel minder hard dan het aantal 65-plussers (bijna 50\%). Dit komt doordat het opleidingsniveau stijgt en het aandeel mensen met een lichamelijke beperking constant blijft.

Maar er is ook minder goed nieuws. De dure zorgpakketten wijkverpleging en verpleeghuiszorg zijn de sterkste stijgers. En net als het NIDI en CBS waarschuwen we dat het aantal ouderen dat zorg en ondersteuning ontvangt stijgt, terwijl de potentiële beroepsbevolking lang niet in dezelfde mate mee stijgt [27]. Dat kan leiden tot een tekort aan mantelzorgers en personeel in de zorg en een stijgend aandeel van zorgpersoneel in de beroepsbevolking. Het CPB ziet een relatieve stijging van de beloning in de zorg als oplossing om het werken in de zorg aantrekkelijker te maken [3]. Inzetten op uitbreiding van het sociale netwerk van ouderen en mantelzorgondersteuning kan helpen mensen te ontlasten die bijvoorbeeld voor een partner met dementie zorgen, en kan zo publiek gefinancierde zorg soms helpen voorkomen, dan wel aanvullen met informele hulp [28].

$\mathrm{Er}$ is wel een aantal onzekerheden, zoals bij vrijwel elke raming het geval is. We gaan uit van de middenvariant van het CBS voor de bevolkingsgroei. Het CBS meldt onzekerheid rond bijvoorbeeld levensverwachting, migratie en effecten van corona [5, 23, 27]. We hebben geen informatie over een aantal verklarende factoren die vanuit de literatuur bekend zijn als be- palend voor het zorggebruik, zoals (het gebrek aan) eigen regie en veerkracht, die beide een dempende werking hebben op het zorggebruik [29]. Ook ontbreekt informatie over betaalde eigen bijdragen, die sterk samenhangen met het inkomen [30]. Omdat er geen ramingen beschikbaar zijn voor deze grootheden zijn de potentiële gevolgen voor de groei van het gebruik niet in te schatten.

Verder gaan we ervan uit dat mensen in 2040 op dezelfde manier afwegingen over zorggebruik maken als in de periode 2014-2016 (de jaren waarin de enquête gehouden is) en dat het beleid niet verandert. De raming geeft daarmee weer hoe het gebruik van zorg en ondersteuning zich ontwikkelt op basis van trends in waarneembare individuele kenmerken. Door beleidsaanpassingen is het gebruik van verpleeghuiszorg sindsdien echter afgenomen en is de zorgzwaarte van verpleeghuisbewoners toegenomen. Hierdoor zou het achterblijvende aanbod van informele hulp (aan mensen met een relatief lichte zorgvraag) tot een kleinere extra vraag naar verpleeghuiszorg kunnen leiden dan onze cijfers aangeven. Desondanks blijven de conclusies onverminderd geldig.

Daarnaast kan de ontwikkeling in gebruik anders zijn als er bijvoorbeeld meer of minder tekorten in het zorgaanbod ontstaan. Verder weten we niet of de zorg die mensen nu en in de toekomst ontvangen toereikend of passend is. Technologische ontwikkelingen, zoals domotica, digitalisering, robotisering en kunstmatige intelligentie, kunnen het bijvoorbeeld mogelijk maken dat kwetsbare mensen langer thuis kunnen wonen of meer op maat bediend worden. Maar het RIVM signaleert ook dat het gebruik van technologie in de zorg langzamer toeneemt dan in ons dagelijks leven. De invloed hiervan op het gebruik van de verschillende zorgvormen is derhalve ongewis.

Duidelijk is echter dat zorg en ondersteuning in de toekomst meer middelen zullen vergen. Ons onderzoek biedt beleidsmakers inzicht in de te verwachten ontwikkelingen in het gebruik van zorg en ondersteuning, en de rol van informele hulp om publiek gefinancierde zorg te beperken. Daarmee biedt het informatie die kan helpen te bepalen op welke punten bijsturing mogelijk is.

Open Access This article is licensed under a Creative Commons Attribution 4.0 International License, which permits use, sharing, adaptation, distribution and reproduction in any medium or format, as long as you give appropriate credit to the original author(s) and the source, provide a link to the Creative Commons licence, and indicate if changes were made. The images or other third party material in this article are included in the article's Creative Commons licence, unless indicated otherwise in a credit line to the material. If material is not included in the article's Creative Commons licence and your intended use is not permitted by statutory regulation or exceeds the permitted use, you will need to obtain permission directly from the copyright holder. To view a copy of this licence, visit http://creativecommons.org/licenses/by/4.0/. 


\section{Literatuur}

1. Verbeek-Oudijk D. Informele zorg ontvangen en verlenen: is de context van invloed? Den Haag: Sociaal en Cultureel Planburau;2019.

2. RIVM. Volksgezondheid Toekomst Verkenning. 2018. https://www.vtv2018.nl/trendscenario. Geraadpleegd op: $14 \operatorname{dec} 2020$

3. Zeilstra A, Ouden A den, Vermeulen W. Middellangetermijnverkenning zorg 2022-2025. Den Haag: Centraal Planbureau;2019.

4. Pickard L, Comas-Herrera A, Costa-Font J, et al. Modelling an entitlement to long-term care services for older peoplein Europe: projections forlong-term care expenditure to 2050. JEurSoc Policy. 2007;17(1):33-48.

5. Centraal Bureau voor de Statistiek. Prognose: bevolking blijft komende 50 jaar groeien. 2020. https://www. cbs.nl/nl-nl/nieuws/2020/51/prognose-bevolking-blijftkomende-50-jaar-groeien. Geraadpleegd op: 16 dec 2020.

6. Von Lengerke T, Gohl D, Babitsch B. Re-revisiting the behavioral model of health care utilization by Andersen: a review on theoretical advances and perspectives. In: Janssen C, Swart E, von Lengerke T, redactie. Health care utilization in Germany. New York: Springer; 2014.

7. Kromhout M, Echtelt P van, Feijten P. Sociaal domein op koers? Verwachtingen en resultaten van vijf jaar decentraal beleid. Den Haag: Sociaal en Cultureel Planbureau; 2020.

8. Kooiker S, Jong A de, Verbeek-Oudijk D, et al. Mantelzorg in de toekomst. Een regionale toekomstverkenning voor de komende 20 jaar. Den Haag: Sociaal en Cultureel Planbureau/Planbureau voor de Leefomgeving; 2019.

9. WoittiezI, EgginkE, Verbeek-OudijkD. Watals zorg wegvalt? Een simulatievan alternatieven voor zorg en ondersteuning voor mensen met een gezondheidsbeperking. Den Haag: Sociaal en Cultureel Planbureau; 2019.

10. Eggink E, Woittiez I, Ras M. Forecasting the use of elderly care: a static micro-simulation model. Eur J Health Econ. 2015;17:681-91.

11. Putman L, Verbeek-Oudijk D, Klerk M de. Zorg en ondersteuning in Nederland: kerncijfers 2016. Den Haag: Sociaal en Cultureel Planbureau; 2017.

12. Verbeek-Oudijk D, Campen C van. Ouderen in verpleeghuizen en verzorgingshuizen. Landelijk overzicht van hun leefsituatie in 2015/'16. Den Haag: Sociaal en Cultureel Planbureau; 2017.

13. Centraal Bureau voor de Statistiek. Prognose personen in huishoudens; leeftijd, burgerlijke staat, 2016-2060. 2018. https://opendata.cbs.nl/statline/\#/cbs/nl/dataset/ 83227NED/table?dl=3CF95. Geraadpleegd op: $14 \mathrm{dec} 2020$.

14. NZa. Monitor Effecten langer thuis wonen-2016. Onderzoek naar de effecten van het beleid langer thuis wonen op de continuïteit van langdurige zorg. Utrecht: Nederlandse Zorgautoriteit; 2016.

15. Centraal Bureau voor de Statistiek. Maatwerktabel 'Aantal extramurale zorggebruikers per jaar, naar (combinatie van) zorgfunctie(s), 2009-2018'. Den Haag: Centraal Bureau voor deStatistiek; 2020.
16. Woittiez I, Eggink E, Verbeek-Oudijk D, et al. Zorg vragen of zorg dragen? Een verkenning naar de rol van netwerken en inkomen op het gebruik van langdurige zorg door Nederlandse 55-plussers. Den Haag: Sociaal en Cultureel Planbureau; 2015.

17. Eggink E, Oudijk D, Sadiraj K. VeVeRa-IV. Actualisatie en aanpassing ramingsmodel verpleging en verzorging 2009-2030. Den Haag: Sociaal en Cultureel Planbureau; 2012.

18. Eggink E, Jonker J, Sadiraj K, et al. VeVeRa-III. Ramingen verpleging en verzorging 2005-2030, modelbeschrijving. Den Haag: Sociaal en Cultureel Planbureau; 2009.

19. Woittiez I, EgginkE, Jonker J, et al. Vergrijzing, verpleging en verzorging. Ramingen, profielen en scenario's, 2005-2030. Den Haag: Sociaal en Cultureel Planbureau; 2009.

20. Andersen R, Newman JF. Societal and individual determinants of medical care utilization in the United States. MilbankMemFundQHealth Soc. 1973;51(1):95-124.

21. BabitschB, GohlD, LengerkeTvon. Re-revisitingAndersen's behavioral model of health services use: a systematic review of studies from 1998-2011. Psychosoc Med. 2012;9:Doc11.

22. Centraal Bureau voor de Statistiek. Prognose personen in huishoudens; leeftijd, burgerlijke staat, 2019-2060. 2019. https://opendata.cbs.nl/statline/\#/cbs/nl/dataset/ 84349NED/table?dl=47B7C. Geraadpleegd op: 20 sep 2019.

23. Centraal Bureau voor de Statistiek. Bevolkingsprognose 2020-2070: bevolking groeit langzamer door corona. 2020. https://www.cbs.nl/nl-nl/longread/statistische-trends/ 2020/bevolkingsprognose-2020-2070-. Geraadpleegd op: 15 mrt 2021.

24. Centraal Bureau voor deStatistiek. Arbeidsdeelname; kerncijfers 2020. 2020. https://opendata.cbs.nl/statline/\#/cbs/ $\mathrm{nl} /$ dataset/82309NED/table?dl=3C843. Geraadpleegd op: $14 \mathrm{dec} 2020$.

25. Centraal Bureau voor de Statistiek. Bevolking; onderwijsniveau; geslacht, leeftijd en migratieachtergrond. 2020. https://opendata.cbs.nl/statline/\#/cbs/nl/dataset/ 82275NED/table?dl=3C844. Geraadpleegd op: $14 \mathrm{dec} 2020$.

26. Centraal Bureau voor de Statistiek. Sterftekansen naar leeftijd, geslacht, opleidingsniveau. 2017. https://www.cbs. $\mathrm{nl} / \mathrm{nl}$-nl/maatwerk/2017/23/sterftekansen-naar-leeftijdgeslacht-opleidingsniveau. Geraadpleegd op: 14 dec 2020.

27. Nederlands Interdisciplinair Demografisch Instituut, Centraal Bureau voor de Statistiek. Bevolking 2050 in beeld. Drukker, diverser en dubbelgrijs. Deelrapport Verkenning Bevolking 2050. Den Haag: Nederlands Interdisciplinair Demografisch Instituut/Centraal Bureau voor de Statistiek; 2020.

28. Klerk M de, Boer Ade, Plaisier I, et al. Voor elkaar? Stand van de informele hulp in 2016. Den Haag: Sociaal en Cultureel Planbureau; 2017.

29. KokAAL. How tough times become good times. Studies on socioeconomic inequality, resilience and successful aging. Amsterdam: Vrije UniversiteitAmsterdam;2019.

30. Vernhout G, Bakker PF, Dragt W. Rapportage verkennend onderzoeknaar opzeggers in de thuiszorgin verband met de verhoging van de eigen bijdrage in 2004. Enschede: HHM; 2004. 